UNIVERSIDADE DE BRASÍLIA

Centro de Excelência em Turismo

Curso de Especialização Para Professores e Pesquisadores em Turismo e Hospitalidade

\title{
A Gastronomia de Paracatu: Elemento Identitário e Diferencial Turístico
}

\author{
Cláudia Costa Brochado
}

Wilma Maria Coelho Araújo

(Orientadora)

Monografia apresentada ao Centro em Excelência em Turismo da Universidade de Brasília como requisito parcial para a obtenção do certificado de Especialista em Turismo e Hospitalidade

Brasília, DF, Fevereiro de 2004 
UNIVERSIDADE DE BRASÍLIA

Centro de Excelência em Turismo

Curso de Especialização Para Professores e Pesquisadores em Turismo e Hospitalidade

\section{A GASTRONOMIA DE PARACATU: ELEMENTO IDENTITÁRIO E DIFERENCIAL TURÍSTICO}

Cláudia Costa Brochado

Wilma Maria Coelho Araújo, Doutora

(Orientadora)

(Banca Examinadora)

(Membro da Banca)

Brasília, DF, Fevereiro de 2004 


\section{AGRADECIMENTOS}

Agradeço, em primeiro lugar, aos professores do CET cujas aportações muito contribuíram para esta pesquisa, notadamente às professoras Cléria Botelho e Wilma Araújo, minha orientadora. Às coordenadoras Maria Tereza Negrão e Tânia Montoro, pelo incentivo. A Vera Medeiros e Luciane Conte pela ajuda na revisão do trabalho. A Helen Ulhôa Pimentel, pelo auxílio na localização das fontes históricas de Paracatu. A minha mãe, Lilia Costa Brochado, pelo auxílio na seleção das fontes orais e bibliografia referente à Paracatu. A Eve Liz Safra por seu estímulo e apoio. Meu agradecimento especial às mulheres entrevistadas, que com cordialidade e paciência me receberam e cujos depoimentos fizeram possível este trabalho. 
Começar pelo canudo, passar ao branco do pastel de nata, doçura em prata, e terminar no pudim?

Pois sim. E o que bóia na esmeralda da compoteira: molengos figos em calda, e o que é cristal em laranja, pêssego, cidra - vidrados?

A gula, faz tanto tempo, cristalizada.

Carlos Drummond de Andrade País do Açúcar 


\section{RESUMO}

As cidades do interior do Brasil são muitas vezes detentoras de forte identidade espelhada em tradições e costumes. A gastronomia, neste contexto, dispõe de amplo potencial para engendrar um diferencial turístico. Também, é espaço de poder feminino, demonstrado pela presença das mulheres como produtoras de alimentos e reconhecidas enquanto autoridade. A cidade de Paracatu, com sua rica história e identidade, é um exemplo disso. 


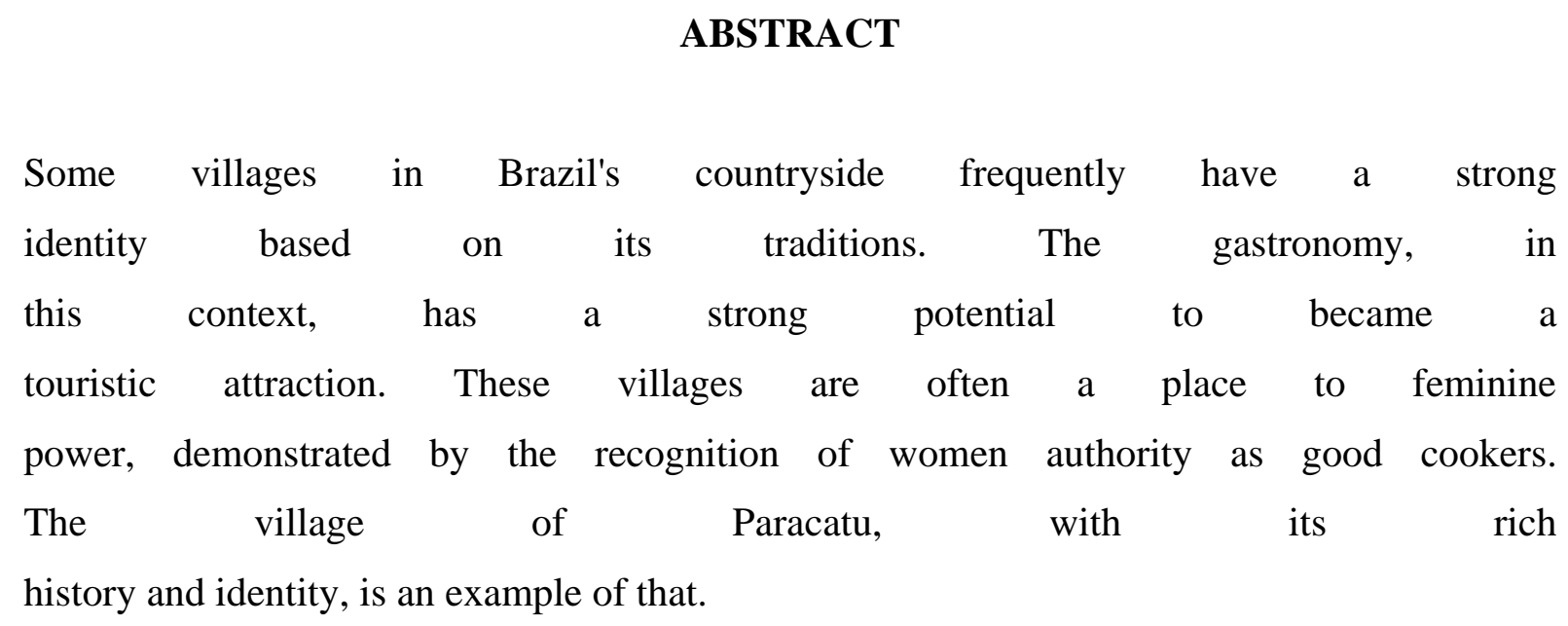


SUMÁRIO

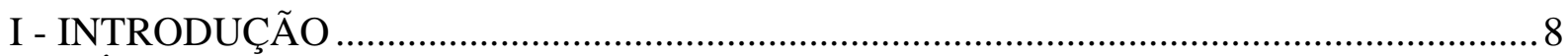

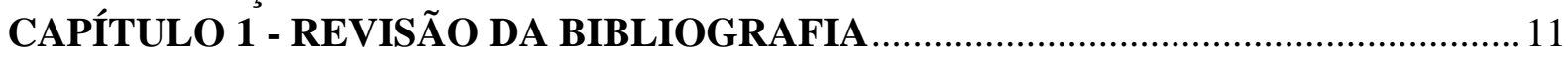

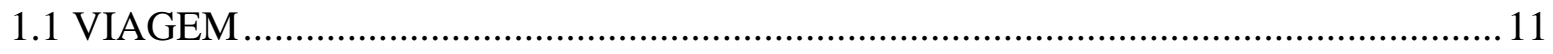

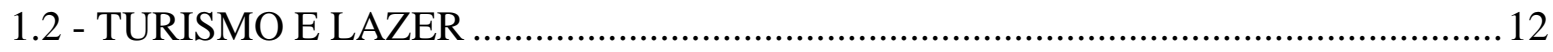

1.3 - PRESERVAÇÃO PATRIMONIAL NO BRASIL ................................................... 15

1.4 - TURISMO, PRESERVAÇÃO E MEMÓRIA ........................................................... 16

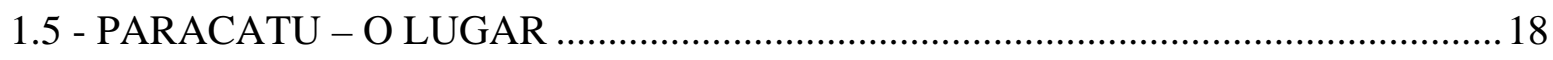

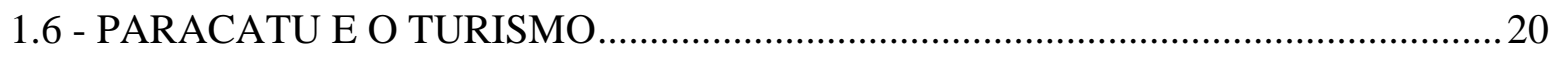

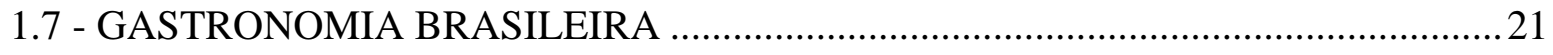

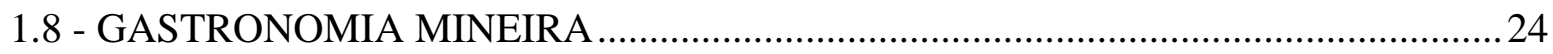

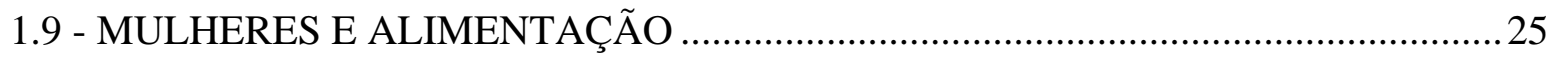

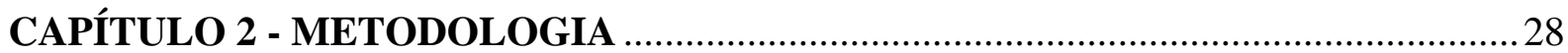

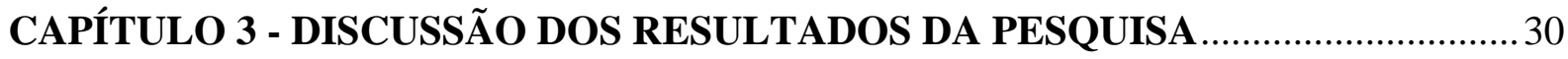

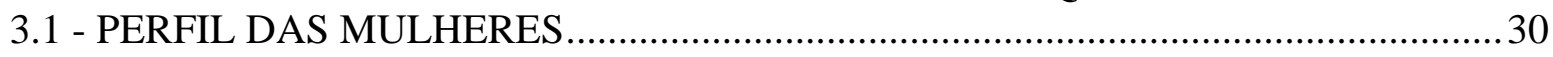

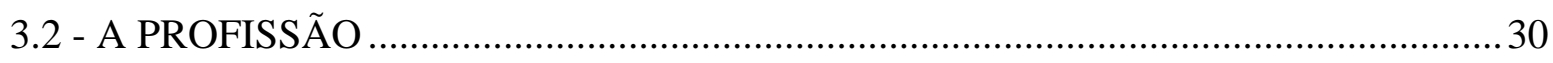

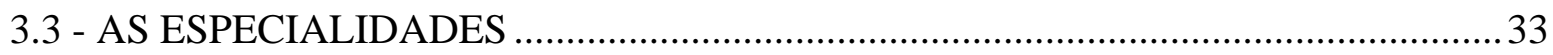

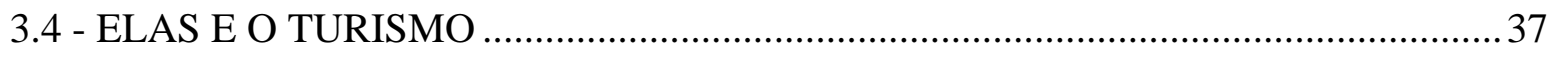

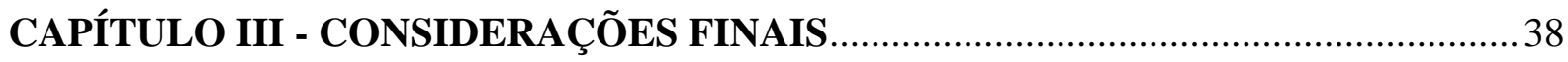

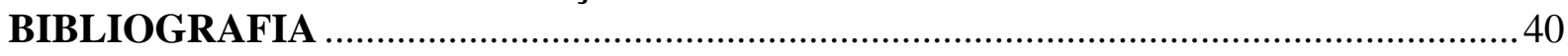




\section{I - INTRODUÇÃO}

No ano passado, estive em Paracatu, cidade onde nasci e para onde sempre viajo para visitar a minha mãe, e recebi das mãos de minha tia, Martha Brochado Adjuto, um caderno de receitas de sua mãe, minha avó paterna, Maria Botelho Brochado. Este caderno, como qualquer repositório de receitas, estava bastante danificado, com a capa quase solta e sem parte das bordas de algumas folhas, principalmente onde os dedos, provavelmente sujos com o preparo em andamento, passavam apressadamente as páginas para que não fosse perdido o ponto.

Foi com a descoberta desta fonte, que surgiu meu interesse em fazer esta monografia sobre a culinária de minha terra natal.

Até então, sempre havia tratado a questão da alimentação como algo empírico, sempre apreciei os quitutes da minha terra, mas poucas vezes pensei sobre eles. Sabia que eram especiais, não porque pessoalmente os apreciava, mas porque percebia a fascinação que exerciam nas amigas e amigos que os provavam quando visitavam Paracatu comigo ou quando eu levava algum quitute para Brasília. Em diversas ocasiões, fiz encomendas a pedido desses/as.

Nas minhas andanças pelo turismo, como coordenadora de curso de graduação, acabei por perceber a gastronomia como um elemento fundamental, que impulsiona as pessoas a viajar, a conhecer novos lugares.

Como historiadora, sempre me interessei pela preservação dos patrimônios, das memórias que dão o sentido de identidade individual e coletiva. E como especialista em História das Mulheres, reconheci a possibilidade de observar o espaço da culinária de Paracatu, como um espaço de autoridade feminina.

Estruturei, então, duas grandes perguntas que procurei percorrer ao longo da pesquisa: no âmbito da identidade de paracatuense, é a gastronomia um forte elemento? No âmbito do espaço/autoridade feminina é a culinária também um forte elemento? Outras perguntas secundárias também surgiram: quais seriam as origens da culinária de Paracatu? Como essa tradição se manteve? Se ela seduz o viajante, o visitante, ela poderia ser explorada como atrativo gerador de renda? Esta riqueza potencial poderia comprometer a outra, a riqueza identitária já existente?

A partir de três eixos, culinária, turismo e identidade feminina, estruturei a minha pesquisa. 
Começo com a revisão da bibliografia relacionada aos temas viagem, turismo, patrimônio, identidade e memória. Posteriormente sobre a história da cidade de Paracatu, a gastronomia no Brasil e em Minas Gerais, para finalizar com a relação mulheres-alimentação.

Posteriormente, apresento o método utilizado para a pesquisa para entrar finalmente na discussão dos seus resultados e apresentar as considerações finais.

Inicio com a discussão em torno da concepção de viagem, na medida em que penso que é partindo da interpretação desse movimento que poderemos entender o fenômeno do turismo. Mostro sua característica de “rito de passagem”, tanto para os religiosos da Idade Média, quanto para os jovens da elite inglesa, no chamado Grand Tour. Mostro que os tratamentos medicinais impulsionaram as primeiras viagens cujas características mais se assemelham às viagens já tipicamente turísticas do séc. XX.

Passo então a analisar o turismo dentro da perspectiva do lazer, fenômeno surgido com as sociedades pós-industriais, discutindo a noção de "tempo livre" como espaço para o turismo. Apresento alguns aspectos do turismo na economia brasileira e a ênfase ao desenvolvimento contido nos planos de governo ou de organismos internacionais, chegando à noção de sustentabilidade em seus vários níveis.

No item referente ao patrimônio, apresento um pequeno histórico do processo de preservação patrimonial no Brasil, principalmente com o surgimento do órgão responsável, o IPHAN, chegando até a Constituição de 1988.

Ao falar sobre a relação turismo-preservação-memória, apresento as críticas atuais quanto à preservação patrimonial em função do turismo, gerando o "espaço mercadoria”, e também das possibilidades que o turismo oferece para a preservação dos bens patrimoniais, tanto culturais quanto naturais.

Apresento as reflexões sobre os impactos da "globalização" nas identidades e a importância da preservação da memória individual e coletiva.

No item seguinte, trato da cidade de Paracatu, falando de sua história e situando-a no contexto da historiografia brasileira, para, em seguida, contextualizá-la na perspectiva do turismo.

Falo da gastronomia no Brasil, suas três maiores influências (indígena, africana e portuguesa) e sua evolução com a introdução de novos componentes: movimento de colonização do séc. XIX, que introduz a culinária de outros países europeus, influência francesa, com a introdução da etiqueta à mesa, entre outros. 
Discuto a relação mulheres-alimento, fortemente presente em várias culturas. Observo também o papel das mulheres como transmissoras de cultura e a importância da culinária nesse contexto, verificando se este seria um espaço de poder feminino.

Falo da culinária e averiguo se é um elemento identitário da cidade de Paracatu. Mostro o papel das antigas cozinheiras negras e das atuais produtoras de salgados e doces para verificar se foram, no primeiro caso, ou seriam, no segundo, elementos fundamentais na preservação das tradições culinárias locais.

Em seguida, apresento a metodologia utilizada na pesquisa, enfatizando a importância da fonte oral e do relato das experiências cotidianas quando tratamos de identidade e memória.

Além das fontes secundárias analisadas para a pesquisa, para chegar-se ao estado da arte, defini como fonte primária as entrevistas concedidas por sete mulheres selecionadas entre as produtoras de salgados e doces de Paracatu.

Ao relatar os resultados da pesquisa com as fontes primárias, divido a análise em três grandes eixos: a profissão, as especialidades e a relação das mulheres entrevistadas com o turismo.

No que diz respeito à profissão, falo dos preços dos produtos, da importância da atividade para a renda familiar, da possibilidade de aumento da produção. Ao observar as relações entre espaço doméstico e as atividades culinárias das entrevistadas, examino como essas mulheres constroem nichos de poder.

Quanto às especialidades, verifico com quem aprenderam, se houve alteração nas receitas originais, qual a aceitação dos produtos.

Finalizo a análise verificando como essas mulheres vêem o turismo, se acreditam que a cidade possui atrativos que possam ser apreciados por outras pessoas, se gostariam que a cidade recebesse mais turistas, se o turismo pode contribuir para a atividade que exercem e para preservação das tradições culinárias da cidade.

O último capítulo destina-se às considerações finais. 


\title{
II - DESENVOLVIMENTO
}

\section{CAPÍTULO 1 - REVISÃO DA BIBLIOGRAFIA}

\author{
1.1 VIAGEM
}

A viagem tem como traço fundamental a necessidade humana de ter contato com o desconhecido, tendo se transformado em tradição, segundo Serrano (2001, p. 38), no Iluminismo. Muito antes disso, no entanto, assiste-se à proliferação das viagens por motivos religiosos que são transformadas em espécie de "rito de passagem” para aqueles/as que desejassem percorrer o caminho da espiritualidade.

No período moderno a prática da viagem surge novamente como "rito de passagem" para os jovens da elite inglesa, o chamado grand tour. Essa viagem tinha propósito educacional e centrava-se no conhecimento histórico e cultural dos países estrangeiros visitados, e tinha em geral, Paris e Roma como destinos (BARBOSA, 2002, p. 33). Esses jovens deveriam alargar os conhecimentos adquiridos nas grandes universidades inglesas, como Oxford e Cambridge, numa grande viagem que tinha como propósito fazer com que esses jovens observassem o mundo fora dos limites da Inglaterra, adquirissem conhecimento e retornassem mais capacitados para as tarefas do seu país. Talvez por essa razão, a viagem fosse financiada pela rainha Elizabeth, razão de ser chamado também de Tour Elizabetano.

Os tratamentos medicinais surgem também como impulsionadores das viagens às instancias termais como a de maior evidência no séc. XVIII, localizada na Bélgica, chamada Spa. A medicina desse momento começa a observar os efeitos terapêuticos da água, resgatando uma das grandes tradições herdadas do mundo árabe e que se manteve em muitos espaços da Europa até finais da Idade Média. A infra-estrutura criada em torno das instâncias termais, com hotéis e restaurantes, e as viagens realizadas para a busca do bem estar físico e psicológico, eram os prenúncios do chamado turismo. No Brasil, há exemplos desse tipo em Campos do Jordão, espaço visitado na busca da cura para tuberculose na década de 30, assim como Caldas Novas, Goiás, cujas águas quentes já eram procuradas no início da década de 20. (idem, p. 46).

Segundo Adyr Balastreri Rodrigues, "viajar autenticamente é partir do conhecido ao desconhecido, de dentro para fora, do interior de si mesmo para o exterior do outro" (RODRIGUES, 2001, p. 27-8). 
Apesar da viagem não se reduzir ao fenômeno do turismo ele parece "constituir o seu principal paradigma social e sociológico atual” (LABATE, 2001, p. 56).

\section{2 - TURISMO E LAZER}

A viagem na contemporaneidade é cativa do fenômeno do turismo, que surge a partir das transformações na organização do trabalho. Nasce em paralelo à concepção de lazer que essas transformações irão suscitar. O lazer é a atividade a ser desenvolvida no espaço de tempo chamado agora de "livre”. Livre de quê? perguntaríamos. Livre do trabalho maçante predominante nas sociedades contemporâneas. O turismo, assim, passa a ser um dos elementos mais importantes das denominadas atividades de lazer que opera a idéia do distanciamento do mundo do trabalho e suas atribulações. O lazer passa a ser refúgio do cotidiano maçante, pouco prazeroso, que é intercalado pelos poucos momentos de prazer que o tempo livre irá oferecer aos trabalhadores da modernidade.

Bruhns (2003, p. 55) prefere a expressão “tempo conquistado” à “tempo livre” já que esse, segundo ela, não está acessível a todos, estando ainda por ser conquistado. Entende que o termo seria mais revolucionário, já que se refere à conquista dos sujeitos sociais e de grupos, "visando à expressão da ludicidade e liberdade mais plena, respectivamente, característica e anseio da existência humana e histórica”. A experiência do lazer está associado à vivência, produção e reelaboração de cultura, onde o turismo surge como importante "locus” de relações interpessoais, de vivência e produção de cultura. Insere-se no processo de globalização das economias e da melhoria nos meios de comunicação e transporte. Envolve o deslocamento temporário de pessoas por razões das mais diversas e abrange hoje praticamente todas as camadas e grupos sociais, diferenciando-se nos serviços utilizados (SERRANO, 2001, pg. 38).

O turismo é a atividade que mais se incumbe do espaço do lazer, ocupando-o com suas diversas variações, definindo-se num sentido mais amplo, como atividade de movimento, da viagem, do sair do espaço da vivência cotidiana para entrar no espaço do novo, do inesperado.

Apesar das críticas quanto ao distanciamento desse princípio, notadamente no que se refere à massificação da viagem, este é o princípio gerador daquilo que se definiu como turismo.

Obviamente, esse movimento trará impactos e esses têm sido estudados por teóricos do turismo que principalmente na última década produziram diversas reflexões a respeito. Esses trabalhos, segundo Margarita Barretto (2001, pg. 18), se centrarão na análise dos impactos ambientais além da perspectiva administrativa e gerencial da atividade. No que diz 
respeito à análise sócio-antropológica, que nos interessa aqui particularmente, a produção ainda é reduzida.

O grande teórico da sociologia do turismo é o suíço Jost Krippendorf, com sua obra de referência escrita em 1984. Ele falará das mudanças na concepção das viagens, quando o lazer passa na pós-modernidade a constituir-se em uma espécie de obrigação. Surge o paradoxo entre o livre arbítrio de ir e vir, adquirido pelo ser humano na modernidade, e a falta dessa, no controle sobre o ser humano exercido pela sociedade de consumo, fenômeno também da modernidade. Liberdade versus manipulação.

A frieza das relações impostas pela vida moderna seria um dos fatores que impulsionam o desejo de viajar, uma fuga a uma realidade de pouco prazer. A viagem entraria então como a forma de "viver a liberdade e procurar um pouco de felicidade" (KRIPPENDORF, 2001, p. 15)

Krippendorf constata que a "indústria do lazer" apodera-se do nosso tempo livre, criando nos indivíduos as expectativas e desejos que a movimentará. Assim, ela mais que válvula de escape para a satisfação das necessidades, seria o próprio gerador das necessidades. Realmente esta necessidade de lazer imposta pela sociedade da pós-modernidade atinge a todos em maior ou menor grau, porém é possível perceber que a cada dia um maior número de pessoas está atendo às manipulações da sociedade de consumo, da qual o turismo de massa faz parte.

O turismo transformou-se em prática social, abrangendo todos os grupos sociais e atingindo tanto o turista quanto o residente. Independentemente da vontade ou do interesse em estar envolvido com a atividade, todos somos atingidos em menor ou maior grau pelos seus impactos.

Os motivos das viagens são diversos e o consumo de bens e serviços dependerão do poder aquisitivo de quem o pratica. Como observa Margarita Barreto (2001, pg. 18-19), no que diz respeito aos aspectos econômicos, temos por um lado os turistas e por outro os prestadores de serviços, fazendo com que o setor seja o de maior impacto na economia mundial .

Segundo Jorge Arbache (2001, p. 66), ao contrário de outros países, o mercado de trabalho da indústria turística no Brasil emprega indiví duos mais qualificados e os rendimentos são mais elevados do que no resto da economia. Com exceção dos trabalhadores de serviços e alojamento (hotel, albergue, pensão, etc) que tem qualificações e remunerações mais baixas, apesar de ser a área de serviços com maiores possibilidades de absorver a mãode-obra local, após a construção civil. É bom lembrar que a análise de Arbache se centra no 
trabalhador dos pólos turísticos ou de grandes cidades, prestadores de serviços em hotéis, restaurantes, etc.

Segundo ele, há também uma elevada e crescente proporção de empregadores e trabalhadores autônomos no setor num mercado flutuante, com alta rotatividade da mão-deobra e uma predominante sazonalidade. Estes aspectos são vistos por alguns pesquisadores como fatores que não contribuem para a democratização desse mercado (ARBACHE, 2001, p. 91).

A concepção do turismo enquanto indústria, muito trabalhada na década de setenta e oitenta, sofre diversas críticas na medida em que priorizava os aspectos econômicos da atividade e desprezava principalmente os aspectos socio-antropológicos.

Apesar de sabermos que o turismo não pode ser a panacéia para a resolução dos problemas econômicos nacionais, acreditamos nas potencialidades que ele detém. Os planos de governo para a área do turismo enfatizam a idéia de que o turismo é fator de desenvolvimento. Não me refiro às concepções de desenvolvimento dos programas de governo, dos discursos da ONU, que manteriam o foco no mercado, ou a Agenda 21, que define economia e mercado como categorias centrais. Trabalharemos a idéia de desenvolvimento sustentável local e participativo, que considera os aspectos naturais, econômicos, sociais e culturais.

Os benefícios econômicos gerados pelo turismo dentro da perspectiva da sustentabilidade, devem atingir todas as esferas da sociedade, trazendo, como conseqüência, a melhoria da qualidade de vida das populações.

No que diz respeito aos aspectos naturais, o meio ambiente é hoje um tema presente em todas as esferas da sociedade. Não se trata mais de pensá-lo enquanto questão ética ou ideológica, mas de sobrevivência. Não importa o partido político, a ideologia, é preciso ter uma postura correta quanto às questões ambientais sob pena de ser enquadrado na categoria dos indivíduos sem cultura. Essa mudança de mentalidade, porém, não tem sido suficiente para evitar prejuízos ambientais dos mais diversos, afinal, o poder econômico continua prevalecendo acima de interesses mais nobres. Apesar da despreocupação com os impactos ambientais significar um marketing negativo para as empresas, em decorrência da mudança de mentalidade que comentei acima, muitas delas assumem esse risco pelo lucro fácil ou em outros casos camuflam os aspectos negativos dos impactos.

A atividade turística durante muito tempo foi fator de destruição ambiental, mas nos últimos tempos, tem sido vista como um potencial fator de preservação. Esta mudança acompanha a transformação de mentalidade surgida a partir da constatação da impossibilidade 
de prescindir da responsabilidade com o meio ambiente sob pena de comprometer a vida no planeta. Mas seria mesmo possível ser o turismo uma arma de preservação? Esta pergunta tem permeado muitas discussões, a maioria delas carregadas de pontos positivos e negativos. Mas eu diria que na impossibilidade de manter ambientes naturais intactos, ele pode constituir-se em uma saída menos agressiva ao meio ambiente. Talvez seja preferível assegurar o controle sobre os espaços a serem preservados do que acreditar que estes permanecerão imaculados. Uma das formas de se fugir dos impactos negativos do turismo é a pesquisa científica e o planejamento, que contribuirão para o desenvolvimento de suas potencialidades sem colocar em risco a sustentabilidade em seus vários níveis.

No que diz respeito à sustentabilidade em seu aspecto cultural, que é o foco desta pesquisa, trabalharemos no próximo item que será dedicado à concepção de patrimônio.

\section{3 - PRESERVAÇÃO PATRIMONIAL NO BRASIL}

A restauração e conservação patrimonial passou a ser assunto de interesse dos governos principalmente no séc. XX, apesar das preocupações com a preservação de monumentos arquitetônicos remontar a finais do séc. XIX, com debates de professores e autoridades européias sobre as questões envolvendo conservação, reconstrução, revitalização de monumentos considerados de valor excepcional (PELLEGRINI FILHO, 2001, p. 92).

O órgão mais antigo da América Latina que tinha como função a preservação do patrimônio histórico e artístico foi criado no Brasil, em 1937, com o nome de SPHAN (Serviço do Patrimônio Histórico e Artístico Nacional). Esse órgão, hoje chamado de IPHAN (substituição de Serviço por Instituto), tem como meta o controle dos bens móveis e imóveis do país cuja conservação seja de interesse público.

Foi um texto de Mário de Andrade que deu as bases para o decreto de criação do SPHAN, apesar de terem sido feitas algumas modificações no texto original. Mário de Andrade falava das "obras de arte pura e aplicada, popular e erudita, nacional e estrangeira” (idem, p. 104). O texto do decreto definido posteriormente fala de bens móveis e imóveis de interesse público, vinculados a fatos "memoráveis da história do Brasil, quer por seu excepcional valor arqueológico ou etnográfico, bibliográfico ou artístico” (idem, p. 105).

Foram precisos alguns anos para que o foco das autoridades envolvidas com as questões de preservação/restauração deixasse de ser apenas os bens patrimoniais antigos pertencentes ao acervo arquitetônico. Isso pode ser constatado no caso do Brasil quando 
observa-se a tendência aos dirigentes do SPHAN serem arquitetos. Na primeira fase de sua criação, principalmente nos anos que Rodrigo de Mello Franco de Andrade esteve como diretor, houve uma corrida para tombar e restaurar bens patrimoniais antigos do acervo arquitetônico.

Esta tendência sofreu uma mudança na década de 1970 com a direção de Aloísio Magalhães, que esteve mais atento à abrangência do conceito de bens culturais, atendo-se à preservação de bens relacionados a grupos minoritários e/ou pouco privilegiados (índios, negros, ciganos etc) (idem, p. 105) Aqui vemos uma maior aproximação ao anteprojeto sugerido por Mário de Andrade.

Na Constituição de 1988 houve uma maior ênfase no patrimônio cultural e também ao natural, que veio definido separadamente.

\section{4 - TURISMO, PRESERVAÇÃO E MEMÓRIA}

A preocupação em atrair turistas que movimentem a economia de estados e municípios tem servido como incentivo à preservação daquilo que é, ou pode vir a ser, atrativo turístico, fazendo com que a atividade venha a auxiliar na preservação efetiva de bens patrimoniais.

No entanto, a preservação de bens em função do turismo, tem suscitado críticas como a de Ycarim Melgaço Barbosa (2001, p. 83) que dirá que o turismo cria o "espaço mercadoria”, e o turista transforma-se em consumidor da memória do passado ou do tempo histórico. Dar-se-ia aqui vida nova a lugares abandonados que ao se transformarem em lugares turísticos, passam ao “domínio do pictórico”. Edificações ganham vida nova, cores vivas, que se transformam em caricaturas de um passado reproduzido, que na maioria das vezes pouco têm em comum com a nova roupagem, que agora tem a função de chamar a atenção ou compor esteticamente uma paisagem.

Nessa necessidade de composição, é necessária a limpeza do lugar e a retirada das pessoas indesejáveis, os marginalizados antigos moradores, que deixam de ter espaço naquele cenário agora montado com a função de dar conforto aos olhares estrangeiros. Vale lembrar aqui das chamadas “zonas de conforto” ou "não lugares”, este espaço turístico recriado como caricatura de um passado que passa a vender-se como mercadoria. 
O patrimônio está relacionado à cultura, ou seja, às manifestações de um determinado grupo que lhe dão um sentido de conjunto, de unidade. A cultura está relacionada à noção de herança, ou seja, da experiência passada de geração à geração num processo acumulativo.

Segundo Ana Cláudia de Aguiar (1987, p. 3) em seu trabalho sobre o patrimônio “estender o conceito de patrimônio histórico e artístico” para “patrimônio cultural” significa compreender que o valor patrimonial de um bem transcende em muito o seu valor histórico comprovado e reconhecido oficialmente, ou as suas possíveis qualidades artísticas” (AGUIAR, 1987, p. 3 )

A valorização do chamado patrimônio de caráter intangível é recente mas justifica-se na medida em que a preocupação de preservação não deve relacionar-se apenas à manutenção das edificações e objetos mas também às tradições populares, os importantes componentes da memória coletiva que dão o sentido de identidade cultural.

Segundo Stuart Hall (1997, p.14) a identidade cultural tem sofrido o impacto da “globalização” que a afeta e transforma. Observa que a identidade está sempre em processo de transformação, de movimento, pela multiplicidade dos sistemas de "significação e representação cultural”, que cria identidades cambiantes e temporárias. No entanto, saber identificá-las e valorizá-las é um passo importante na busca da preservação da memória individual e coletiva.

Com o enfraquecimento das identidades corremos o risco de perdermos o sentido de nós mesmos como sujeitos integrados, composto não de uma, mas de muitas identidades (idem, 1995, p. 18)

Segundo Pollak (1992, p.204), a memória é um elemento fundamental na construção do "sentimento de continuidade e de coerência de uma pessoa ou de um grupo em sua reconstrução de si” pois constrói a identidade individual e coletiva, não se referindo apenas a vida física.

Os “lugares da memória” estudados por Pierre Nora (1989, p. 3-15), como o patrimônio arquitetônico, as paisagens, os personagens históricos, as tradições e costumes, o folclore, a música e a culinária, fortalecem o sentido de pertencimento a um grupo, a uma coletividade.

A gastronomia é um dos mais significativos espaços de preservação da memória coletiva e mesmo com a tendência à padronização dos costumes alimentares, se apresenta como forte fator de resistência cultural. Inseridos num movimento dinâmico denominado, não sem críticas, de "globalização”, resta-nos o apego a determinados elementos que nos dê identidade. Garcia (2003, p. 483), comparando os hábitos alimentares tipicamente 
estadunidenses e europeus, observa que, ao contrário do primeiro, o hábito europeu continua prevendo um espaço e um tempo reservados às refeições e que este deve derivar da “valorização e do sentimento de pertencimento manifestado na gastronomia, de modo que a alimentação nutre a identidade cultural” (idem, p. 489)

Walter Benjamin será um dos precursores da preocupação com a preservação da memória constatada em seus escritos sobre suas recordações de infância em Berlin. Ele entra na memória de sua infância registrando a cidade e o mundo cultural e os valores vividos pelos seus pais. Fala também das cores daquelas memórias, dos hábitos cotidianos de lavar as mãos, de tomar a sopa. Os registros que lhe são mais fortes envolvem as sensações dos cheiros e sabores experimentados em sua infância: as amêndoas açucaradas, as geléias, o pão, mel (apud BOLLE, 1984, p. 12)

\section{5 - PARACATU - O LUGAR}

Até o presente falei de patrimônio, de memória e identidade, escolho agora um lugar onde possamos observar os aspectos até aqui trabalhados. Começo perguntando o que seria lugar? Eu diria que ele é o espaço que reúne características identitárias, uma especificidade espacial, social e cultural. Possui também um nome, signo que lhe é impresso, carregado de significados que se transformam com a passagem do tempo, físico e histórico. Quando o lugar é uma cidade, a delimitação se faz mais forte pois ser cidadão, ou seja, ter direito aos privilégios de pertencer àquele lugar, principalmente a partir da Idade Média, com a pulverização do grande Império Romano e a proliferação das cidades como espaços de segurança num mundo hostil, significa carregar em si as marcas daquele lugar. Ele, por si só, já dirá muito de seus habitantes, falará de sua origem, de sua formação, de seus hábitos e costumes, de suas tradições.

Paracatu está localizada no centro geográfico do chamado Mundo Novo. Novo para os que aqui chegaram e que assim denominaram o espaço que acabavam de conhecer, a América, e que apesar de conhecerem pouco do mundo ainda a ser desvendado, acreditavam ser o centro dele. O habitante desta terra era o outro, o desconhecido, o selvagem, aquele que deveria ser descoberto, iluminado, civilizado.

O nome do lugar é da língua dos que aqui habitavam, menos por respeito a eles e mais pela necessidade de se localizarem no novo espaço, imenso, misterioso, indecifrável, cujas referências topográficas eram um dos únicos meios de se moverem com alguma segurança. 
Este era o nome do rio que desceram um dia na busca por metais preciosos, em agrupamentos de homens brancos, ávidos por riquezas mais fáceis que a cana-de-açúcar, já em fase menos gloriosa. Carregavam bandeiras, enlouqueciam naquela vastidão sem fim. Quando não encontravam metais, ou mesmo encontrando-os, justificavam a expedição aprisionando nativos e negros fugidos.

Foi por meio dos registros das bandeiras que temos as primeiras referências ao topônimo Paracatu, principalmente a de Nicolau Barreto que sai de São Paulo em 1602 e retorna à Capitania de São Vicente com mais de 3.000 índios capturados (MELLO, p. 2002, p. 75). Nestes contatos feitos pelo homem branco em princípios do séc. XVII, já foi possível comprovar a existência de ouro, mas estas somente foram exploradas efetivamente no século seguinte.

Antes e durante o movimento das bandeiras havia por essa região criadores de gado que por ali passaram ou se fixaram, tendo construído pequenos núcleos que serviram também aos bandeirantes. Porém não há registros que comprovem que estes temporários povoamentos tenham sido os precursores do arraial que se formaria depois com o Manifesto Legal da descoberta das minas de Paracatu, em 1744.

Nos registros existentes, os índios da região eram os Amoipira, Temiminó e Tamoio (BERTRAN, 2000, p. 29-54). Os últimos eram originários do Rio de Janeiro de onde já tinham sido expulsos. Foram obrigados a se deslocarem da região onde viviam, como as demais tribos que habitavam o litoral, para fugirem do homem branco.

Paracatu significa na língua tupi-guarani “rio bom”. Se o nome é uma variação de Piracatu, como consta em alguns registros do séc. XVII e como querem alguns como Afonso Arinos de Melo Franco, seu filho mais ilustre, ou o naturalista Saint-Hilaire, que por lá passou no início do séc. XIX, significaria “peixe bom”.

A descoberta das minas de ouro de Paracatu aconteceu quando o chamado Ciclo do Ouro já dava sinais de decadência, e para lá se dirigiram grandes contingentes, ávidos pelo enriquecimento rápido. O apogeu da mineração em seu território durará apenas algumas décadas e quando é erigida à categoria de Vila por D. Maria I, com o nome de Paracatu do Príncipe, já está em decadência. A pecuária passou a representar, a partir daí, o elemento econômico mais importante.

O paracatuense de hoje ainda fala com nostalgia de seu passado de glória, relembra também a fama que já teve de cidade culta, impulsionada por sua Escola Superior, criada por decreto régio em 1821. Fala também do seu teatro, O Philodramático, construído em 1888, que recebeu companhias teatrais brasileiras de destaque na primeira metade do séc. XX e 
serviu de palco para as apresentações teatrais dos nativos. O teatro foi demolido em 1952, no contexto desenvolvimentista brasileiro (MARTINS, 1998, p. 117-18).

Neste século o estrangeiro retorna à Paracatu, antiga conhecida dos exploradores de metais, foram necessários dois séculos para que a técnica fizesse possível a extração do que havia restado da exuberância mineral do passado. O ouro de outrora, que existia na superfície da terra ou nas águas dos rios, há muito já havia fugido para o Velho Mundo, restando agora aquele que se escondera no interior da terra, como os antigos habitantes que adentraram o país na esperança de sobreviver ao invasor.

A empresa mineradora inglesa que se instalou na região na década de setenta, com a anuência das autoridades brasileiras, começa um processo de remoção lenta e gradual do chamado Morro do Ouro, processo vagaroso que demandava a retirada de toneladas de terra para conseguir-se algo de ouro. Mas o morro era grande e somando-se terra e mais terra ao longo de mais de duas décadas, acredito que tenha sido monetariamente compensador para a empresa inglesa (e menos para o Brasil) fazer desaparecer o Morro do Ouro, espaço carregado de histórias e lendas, que no plano da memória coletiva do lugar, que nasceu também por sua existência, ainda tanto tem a contar na voz dos moradores mais velhos, conhecidos contadores de histórias.

Já no plano físico, não há mais registros do morro, a não ser em fotografias, já que nada restou daquele que era a porta de entrada da cidade, que lhe dava aconchego, a protegia e compunha sua entrada. Ficou no lugar um grande buraco de terra vermelha, que nas cheias se enche de água com alto teor de mercúrio.

Alí se deu o desmanche da paisagem, desta vez não pelo turismo, mas por interesses econômicos de outra natureza. Talvez um novo prefeito queira um dia providenciar uma nova porta que tenha como função avisar que se chegou no lugar "Paracatu”, nos moldes das que se proliferam por um Brasil que se tenta apressadamente "turistificar”, mas esta será um mero arremedo daquela que naturalmente lhe emoldurou um dia.

\section{6 - PARACATU E O TURISMO}

Sem muitas possibilidades de se expandir economicamente fora do contexto das grandes explorações agro-pecuárias, que se encontram nas mãos de poucos, resta aos demais habitantes envolvidos com o setor produtivo, pensarem em novas formas de tirar rendimentos, já que as antigas, deixaram de ser lucrativas, pelas mudanças na forma de exploração 
econômica do campo, que a maioria dos antigos proprietários não acompanhou. Hoje alguns moradores da cidade percebem que o espaço onde vivem detêm atrativos que podem interessar aos de fora e, tendo ouvido falar no "chamado turismo”, tentam encontrar maneiras de o explorar. A prefeitura, em mais de uma gestão, definiu políticas que, apesar de pouco efetivas, produziram alguns inventários da cidade e programas de marketing, divulgando-a em centros urbanos próximos, como é o caso de Brasília, que se encontra a pouco mais de 200 quilômetros.

Paracatu detém um importante acervo arquitetônico colonial de casas e igrejas, ruas, becos e praças e alguns espaços institucionais em edifícios antigos restaurados, como o Museu Municipal, o Arquivo Público (o prédio aqui não é uma restauração mas uma tentativa de réplica do primeiro sobrado de Paracatu, que diz ter sido moradia da conhecida personagem, Dona Beija, que residiu na cidade durante algum anos), Câmara Municipal e Casa de Cultura.

Há cachoeiras, rios e riachos e outros tantos atrativos naturais típicos da região-centro oeste. Os atrativos encontram-se em propriedades particulares, cujos donos, em sua maioria, não possuem condições financeiras para instalar uma infra-estrutura que pudesse atender a um fluxo permanente de turistas, única forma de garantir um retorno financeiro ao investimento. Aqueles que têm condições econômicas, não estão interessados no turismo, já que lucram com as formas tradicionais de exploração rural.

Outro obstáculo é a falta de uma estrutura urbana que possa garantir outras opções aos que lá chegam, como restaurantes e pousadas com algum atrativo, um comércio com produtos artesanais, mais estrutura para os eventos já existentes: festividades religiosas, feiras, carnaval, datas comemorativas, etc.

A proposta aqui apresentada, de valorização da gastronomia da cidade insere-se neste contexto, já que a vejo como um traço marcante da cidade que, ao ser valorizado e divulgado, pode constituir-se em forte atrativo turístico para a cidade.

\section{7 - GASTRONOMIA BRASILEIRA}

A famosa Carta de Caminha faz menção às grandes possibilidades produtivas da terra que acabava de conhecer dizendo que nela, em se plantando, tudo dá. Este era o aspecto que ela tinha aos olhos do colonizador. No entanto, o paladar dos que aqui habitavam não 
suportou a comida do seu futuro invasor, que neste primeiro contato, mostrou cordialidade para com o anfitrião que o recebia, oferecendo-lhe sua comida.

A primeira mistura que se fez no Brasil foi entre esses dois elementos: o branco e o índio, e a culinária nativa indígena misturou-se à portuguesa: farinha de mandioca, milho, feijão, peixe com o sal e o açúcar. O português introduziu também o gado, os cítricos e as especiarias já comercializados pelos português em outras terras.

Os antigos pratos portugueses, de forte influência moura (lembremos aqui dos séculos de presença árabe na Península Ibérica) foram adquirindo novas variações com a diversidade de produtos aqui encontrados e a forma diferente de prepará-los. Às frutas nativas, juntou-se a cana de açúcar já conhecida dos portugueses, e assim surgem os doces típicos brasileiros aos que acresciam-se também especiarias que lhe dava um sabor exótico apreciado pelo paladar do viajante que por aqui passava (ORNELLAS, 2000, p. 229).

Com a chegada do negro em terras brasileiras e a maior presença desse nas atividades domésticas, sua influência no preparo dos pratos brasileiros é bastante forte. O uso de dendê, coco, quiabo, cebola, alho, pimenta e outros condimentos já conhecidos pelos mercadores portugueses em seus contatos na Ásia, África, Ilha da Madeira e Cabo Verde.

A introdução da pecuária está bastante relacionada à cultura negra do sul da África que já havia aprendido com a maometana do norte a atividade pastoril, utilizando a vaca, a cabra e o carneiro (idem, p. 230). Como o islamismo era forte no Sudão Ocidental e grande parte dos africanos que para cá foram trazidos eram originários desta região, supõe-se que os turbantes usados pelas pretas vendedoras de comida foram inspirados no turbantes muçulmanos.

O colonizador português tentou manter aqui os seus hábitos alimentares, introduzindo no Brasil vários produtos como grãos, frutas, vegetais, animais. Gilberto Freyre constata que será com a Casa Grande, típica da cultura açucareira, que será instaurada a separação entre a mesa do rico e a do pobre. Para a Casa Grande: pipas de vinho, barris de azeite, azeitonas, queijos, defumados etc. (idem, p. 233)

Os mercados de São Paulo são citados como abundantes, mas em outras regiões, registra-se a escassez de produtos a serem adquiridos nas cidades, já que praticamente tudo se encontrava nos espaços privados das grandes propriedades agrícolas, onde tudo se produzia e onde tudo também permanecia. O comércio era bastante incipiente, não sendo comum encontrar produtos à venda. 
Com a riqueza das regiões açucareiras, vemos a chegada das ordens religiosas que se fixaram em conventos e fundaram colégios. Nestes espaços mantinha-se a tradição culinária trazida principalmente da Península Ibérica com forte influência árabe.

No início do séc. XIX já era comum ver negras vendendo quitutes nas ruas dentro dos típicos tabuleiros. E passa a ser tradição nas festas, ceder as escravas quituteiras para preparar os pratos . Muitas receberam a liberdade em função do seus dons culinários (idem, p. 242).

Trigo (2000, p. 166), em seu livro Viagem na Memória, fala das “casas de pasto” que forneciam refeições simples para os viajantes em São Paulo já em final do séc. XVI. O primeiro registro deste tipo de estabelecimento data de 1599.

Neste mesmo período é possível constatar uma mudança nos hábitos alimentares do Brasil com a vinda da corte portuguesa para cá. D. João VI trouxe consigo especialistas em cozinha e depois mandou vir da Europa um chefe de cozinha francês. Era o início de um processo de devoção ao refinamento francês e o menosprezo à cozinha nativa. Com a abertura dos portos, veremos uma propagação de comerciantes que adentravam o Brasil com seus produtos, vindos principalmente da Europa, para satisfação da elite que se formava, ávida por ascensão social e aproximação com os mandatários português.

Com a independência, temos a primeira onda de imigração européia com suas influências na culinária: salsichas alemãs, massas italianas. Também vemos a influência francesa e inglesa.

A culinária francesa já tinha influenciado a portuguesa desde o séc. XVII, especialmente na corte, com suas saladas, sopas, frituras, molhos, recheios e a famosa pâtisserie (ORNELLAS, 2000, p. 242). Mas as inovações que aqui se faziam nas receitas francesas eram elogiadas pelos próprios franceses que aqui estiveram, que elogiavam a variedade de doces e a habilidade das quituteiras brasileiras em introduzir produtos nativos nas receitas, intensificando seu sabor. Um certo médico francês que por aqui passou chega a citar um famoso cozinheiro francês da época (Caréme), dizendo que este empalideceria frente à variedade dos nossos doces e que deixaria pasmo um outro confeiteiro (Barthllenot) a habilidade das quituteiras (idem, p. 242)

Na Revolução de 1817 foram abolidos o pão e vinhos franceses, substituídos pela mandioca e cachaça nacional e o brinde era contra a tirania real e os portugueses na Europa, mostrando que a culinária já era nesse momento um fator de identidade nacional.

Com Pedro I no poder, retorna-se aos hábitos europeus da corte e carregamentos de iguarias européias continuaram a chegar. A Inglaterra vai impondo sua presença, com a 
introdução do hábito da cerveja. Surgem também os primeiros restaurantes italianos e franceses (TRIGO, 2000, p. 166-7)

Vemos a chegada de colonos alemães no sul, italianos em São Paulo e um certo cientista inglês dirá: o imigrante esquece mais depressa o idioma do que os hábitos alimentares (ORNELLAS, 2000, p. 244).

Chegam as massas, o molho de tomate, o queijo ralado, a polenta, gelados, risotos, o gosto pelo vinho, propaga-se o consumo do trigo.

Debret (1816-1831) registra a venda de produtos finos europeus na Rua do Rosário, no Rio de Janeiro. Aos poucos vai se propagando a influência francesa em nossa culinária, na divulgação das receitas importadas e com manuais de boas maneiras que já se publicam em 1872 (ORNELLAS, 2000, p. 247-8).

No entanto, no dia-a-dia e nas famílias menos abastadas, os pratos mais simples, já típicos da terra, predominam: canjica, melado com farinha, milho, os doces de abóbora e batata doce etc.

\section{8 - GASTRONOMIA MINEIRA}

A cozinha mineira é considerada como tipicamente brasileira, com pouca influência estrangeira, além de ser diversificada dentro do próprio estado. Considerada como culinária do viajante, os primeiros que lá chegaram em busca de metais preciosos, que necessitavam viajar grandes distâncias, sem condições de se abastecer com freqüência pela escassez de produtos alimentícios à disposição (ARAÚJO et al., 2002). Quando os primeiros habitantes começaram a chegar às chamadas regiões das minas, se preocupavam apenas com a extração de metais e todos os braços deveriam ser usados para esse fim. Será somente mais tarde, por volta de meados do séc. XVIII, que o abastecimento se faz mais fácil e a mão de obra feminina escrava, principalmente, começa a cuidar da produção de alimentos para abastecer a população ávida por enriquecer com os metais.

Assim surgem o arroz de carreteiro, o feijão tropeiro, com a predominância do porco (principalmente a lingüiça) que era de mais fácil conservação.“Com a decadência da extração do ouro, a agricultura de subsistência e a pecuária desenvolveram-se, a indústria de laticínios prosperou. Leites, queijos (o queijo-de-minas), doce de leite e pão de queijo representam a evolução no âmbito alimentar” (ARAÚJO et al., 2002). 
Um dos primeiros registros sobre a culinária de Paracatu é dada por Emanuel Pohl (1976, p. 102), naturalista austríaco que passou por Paracatu em 1818: “Os alimentos aqui não são excelentes nem sequer de fácil digestão. Arroz, toucinho, legumes, carne de vaca, fresca ou seca ao sol, chouriços defumados, bacalhau, frutas em conserva e doces...”. A simples descrição destes pratos já deixaria de água na boca grande parte dos brasileiros de hoje, como deixava os brasileiros de quase dois séculos atrás. Diferenças culturais, como se sabe.

Afonso Arinos de Melo Franco (sobrinho) mostra também sua admiração pela culinária da terra do seu pai e tio, admirando o fato de não ter sofrido a influência do "suplício das maioneses e outras iniciativas alienígenas com que, erradamente, nos brindam certos amigos do interior” (MELLO, 2002, p. 322).

\section{9 - MULHERES E ALIMENTAÇÃO}

A alimentação diz muito sobre os grupos humanos, tanto no que diz respeito aos aspectos mais abrangentes como, por exemplo, de um país, quanto aos mais específicos, de regiões e cidades. Fala em forma de sabores, texturas, cheiros, na maneira como o preparamos e o degustamos, fala sobre o que somos e como nos relacionamos uns com os outros. É um dos elementos culturais mais profundos e arraigados, difícil de ser transformado ou substituído por outro. Mesmo com a introdução de novas variedades, muitas vezes mais condizentes com a vida atribulada que demanda pressa no preparo dos alimentos, ou com a introdução de modismos divulgados por um sistema de mídia cada vez mais penetrante na vida cotidiana, os hábitos alimentares da infância, permanecem, povoam nossa imaginário com seu forte apelo afetivo. Os gostos nos trazem sensações de prazer ou de angústia. Os de angústia talvez sejam aqueles que, mesmo que sejam nossos conhecidos, não suportamos, repudiamos. Os que nos dão prazer, nos remetem a sensações já experimentadas, de conforto, alegria, segurança. Voltar a estes sabores significa reviver essas emoções.

Experimentar novos sabores, por outro lado, significa a possibilidade de viver novas emoções, novos prazeres, arriscar-se, aventurar-se na promessa da satisfação. É por essa razão que são parceiras as experiências de vida mais abertas ao mundo e o maior refinamento no paladar. Refinamento aqui que nada tem a ver com hierarquização das tradições alimentares ou dos alimentos e seu preparo, mas com o apuramento do gosto alimentar, do ecletismo do gosto que faz permanente o desejo pela aventura de um novo sabor. 
Alimentos e mulheres foram sempre duas categorias que caminharam juntas. Se quiséssemos encontrar o princípio dessa tradição tão difundida entre as culturas do mundo conhecido, chegaríamos ao mais simples, ao biológico, que sempre serviu para explicar grande parte dos aspectos culturais, principalmente antes dos antropólogos virem nos resgatar do positivismo das explicações simplistas, carregadas de preconceito e intencionalidade. Mas, neste caso, penso que a explicação biológica não pode ser negligenciada, já que o primeiro alimento que provamos sai de um corpo de mulher. Além de suas propriedades nutritivas que farão possível nossa sobrevivência extra-uterina, estabelecemos uma relação associativa entre aquela que nos sacia a fome e o alimento que ela traz consigo. É ela que nos liberta desta primeira dor, a fome, no aconchego da pele e do calor do corpo.

As mulheres sempre foram grandes transmissoras de cultura já que suas experiências são passadas oralmente e cotidianamente de geração à geração aos homens e principalmente às mulheres da família. A tradição culinária é uma dessas experiências, uma das mais fortes e arraigadas, como já foi dito, talvez em função da necessidade de reviver aquela primeira sensação de satisfação, de segurança.

No que diz respeito ao Brasil, já falei sobre a cozinheira negra, aquela que preparava os alimentos, os quitutes, para estarmos mais próximos à sensação de sabor, e a sua presença forte na tradição culinária brasileira. Foram responsáveis por comandar cozinhas em todos os cantos do Brasil, principalmente da metade norte do país. Estabeleciam, com as famílias em que estavam inseridas, uma relação de poder bastante significativo no plano da vida da casa, da vida privada. Teresinha Neiva Miranda, assim falará sobre Alexandra, a negra que sempre viveu com sua família, em Paracatu:

Era sempre a ela que a gente dirigia, pedia, ou manifestava nossas vontades. Ela dava ordens, dizia sim ou não conforme lhe convinha, nem consultava a mamãe e foi sempre assim: Alexandra falou água aparou... ninguém contestava (MIRANDA, 1992, p. 12)

Apesar da exploração de sua força de trabalho, pouco ou nada remunerada, eram consideradas parte da família, com autoridade no espaço da cozinha e da alimentação. Grande parte da nossa tradição culinária vem da imaginação e autonomia dessas mulheres, que inventavam pratos, alteravam receitas, muitas de origem estrangeira, ditadas pelas senhoras da casa. Já que em sua maioria não sabiam ler, eram obrigadas a decorar as receitas. Provavelmente deveria escapar um detalhe ou outro que as levavam a modificá-las. Com sua intuição e experiência, tornavam-nas mais saborosas ao gosto brasileiro. 
Com a redefinição da estrutura familiar brasileira e a mudança de hábitos alimentares, a presença da cozinheira é hoje cada vez mais restrita às famílias cujos membros são mais velhos e localizados principalmente em cidades do interior.

Em Paracatu as cozinheiras sempre foram figuras marcantes e, certamente, são umas das maiores responsáveis pela riqueza culinária local e pelo fascínio que esta exerce nos nativos.

Sua tradição culinária tem sobrevivido a diversas influências, principalmente a última e talvez, a maior delas, que foi a proximidade com a capital federal, Brasília.

Brasília e sua modernidade teve forte influência na estrutura física e humana da cidade de Paracatu. Impulsionou o asfaltamento de ruas, em detrimento da antiga pavimentação de pedras; a substituição das fachadas antigas das casas, pelas fachadas típicas da década de sessenta e dos antigos postes elétricos de haste de madeira, pelos modernos de concreto, etc.

A culinária, porém, sofreu pouca variação, talvez porque este hábito seja mais arraigado no ser humano e custe mais a sofrer influências ou talvez porque seus habitantes, pouco atentos a perda do seu patrimônio arquitetônico, não tiveram o mesmo entusiasmo “modernista”, no que diz respeito à alimentação.

Não sendo uma cidade turística, Paracatu nunca teve bons restaurantes ou cafés. A produção culinária sempre se fez para os familiares ou amigos que, obviamente, nunca pagaram pelo que consumiam.

Exceção a isso são as doceiras que trabalham em casa e vendem seus produtos por encomenda. São de uma variedade impressionante, porém cada uma dessas doceiras ou fazedoras de salgados são detentoras de uma especialidade e seus nomes vinculam-se aos quitutes que preparam: Lavínia da Queijadinha, Lucinha da Empadinha, Dalva do Suspiro etc. É sobre estas mulheres que pretendo falar mais a frente. 


\section{CAPÍTULO 2 - METODOLOGIA}

Além das fontes secundárias analisadas para a pesquisa, para chegar-se ao estado da arte, defini como fonte primária as entrevistas concedidas por sete mulheres selecionadas entre as produtoras de salgados e doces de Paracatu. Escolhi fontes orais porque vejo o relato das experiências cotidianas como fundamentais para tratarmos de identidade e memória, além destas mulheres serem efetivamente importantes para a tentativa de encontrar respostas aos questionamentos formulados no início da pesquisa.

A escolha das entrevistadas foi feita de acordo com os seguintes critérios: serem reconhecidas entre seus pares, serem produtoras de especialidades tradicionais da cidade e suas especialidades serem diversificadas e como o meu interesse não era o da análise quantitativa e sim qualitativa, estas sete mulheres serviram de amostragem de uma realidade, obviamente, mais ampla.

Defini um questionário que serviu, no entanto, mais como base para a entrevista, já que o meu interesse era o de que as mulheres não apenas respondessem aos meus questionamentos, mas que falassem também daquilo que desejassem.

Apenas duas entrevistas não foram gravadas. Uma delas pela impossibilidade de seguir a entrevistada pela cozinha, que não pôde parar para a entrevista. A segunda não quis ser gravada.

As perguntas previamente estruturadas para a entrevista foram sendo respondidas, muitas vezes, sem que eu as formulasse efetivamente. Além dos dados como nome, idade, estado civil e local de nascimento, contava do meu roteiro as seguintes perguntas:

- quais os doces ou salgados que produz e com quem aprendeu

- se os comercializa

- há quanto tempo os produz e se produz hoje mais ou menos que antes

- qual a importância do trabalho para a renda familiar

- se vê o trabalho como uma profissão e se este lhe dá prazer

- se sente que o trabalho é valorizado pelos membros da família

- se os seus produtos são mais ou menos valorizados hoje em dia em Paracatu

- se alteraram as receitas 
- se percebem que Paracatu tem uma tradição culinária importante e se acreditam que as mulheres tem um papel importante aí

- se sentem que esta tradição está se perdendo e se temem que ela se perca

- se gostariam que mais pessoas conhecessem os seus produtos

- se teriam condições de aumentar a produção

- o que acham do turismo e se pensam que Paracatu tem algo que possa interessar ao visitante

Nomes e idades das entrevistadas:

- Maria Lúcia Carvalho Barbosa ou Lucinha (47 anos)

- César Gonçalves Santana (60 anos)

- Lazy Ulhoa Bijos (67 anos)

- Vânia Lúcia Neiva Pereira (39 anos)

- Eugênia Maria de Jesus (54 anos)

- Maria Irene Botelho de Sá ou Leninha (68 anos)

- Lavínia Araújo Ramos (65 anos) 


\section{CAPÍTULO 3 - DISCUSSÃO DOS RESULTADOS DA PESQUISA}

Como já disse, as fontes primárias analisadas para este trabalho constituíram-se em entrevistas com mulheres que produzem doces e salgados em Paracatu.

As sete mulheres entrevistadas em um roteiro informal, abordaram diversos assuntos relacionados ou não aos direcionamentos deste roteiro. A seguir apresento alguns temas por mim destacados desenvolvidos pelas mesmas em suas conversas.

\section{1 - PERFIL DAS MULHERES}

Das sete mulheres entrevistadas, seis são casadas e uma é viúva. Apenas uma não tem filhos e as idades variam entre 39 e 67 anos, sendo quatro delas com idades acima dos sessenta anos.

Apenas Eugênia Maria de Jesus, de 54 anos, não é nascida em Paracatu, mas se sente de lá já que, como disse, foi pra lá menina . Praticamente todas são de famílias humildes e muitas trabalham em casas de famílias mais abastadas ou remediadas da cidade. Apenas César Gonçalves Santana saiu de Paracatu para trabalhar como cozinheira na Velhacap, em Brasília, e depois empregou-se como doméstica “em casa de família” no Núcleo Bandeirante. Casou-se e retornou a Paracatu para a mesma rua onde nasceu "num chão de capim que havia alí", como disse.

\section{2 - A PROFISSÃO}

Com exceção de uma, todas as mulheres vêem a atividade que desenvolvem como profissão, apesar de não terem registro profissional, não pagando impostos, nem tendo direito à aposentadoria.

Há mais de 30 anos, Lavínia produz o único produto que comercializa, a queijadinha, e vende a receita, que "rende umas 300 queijadinhas", a R\$ 50,00. A venda depende das encomendas, assim como Lazy, que produz diversos pratos, além de doces e salgados, sempre dependendo das encomendas. Os seus produtos são mais elaborados e os preços mais elevados, já que, como diz, só trabalha com produtos de primeira: 
O cento de seus salgados custa entre 25 e 40 reais.

Eugênia faz diversos tipos de doces para vender: cocada branca, cajuzinho, olho-desogra, amor em pedaço, bombons etc. Vende o cento em média a R \$18,00. Começou há mais de 20 anos, quando lhe pediram que fizesse doces para o aniversário da vizinha de sua patroa. A partir de então nunca mais parou.

César faz o Bolo de Domingo há 15 anos e a unidade custa R\$ 0,60. Vende em sua casa, onde as pessoas vão comprá-lo aos domingos apenas e aproveitam para tomar café. Além de fazer o bolo, lava e passa roupa.

Vera Lúcia faz há 19 anos salgados, principalmente empada e pão-de-queijo. O cento custa $\mathrm{R} \$ 20,00$.

Há 35 anos Maria Lúcia faz também salgados, principalmente a empada, sua especialidade. O cento das pequenas custa $\mathrm{R} \$ 20,00$ e das maiores $\mathrm{R} \$ 22,00$.

Apenas Leninha não sente que a sua profissão seja de produtora de doces ou salgados, já que diz que somente comercializa esporadicamente. Faz bom-bocado, amor-em-pedaço etc. De todas elas, é a que tem a situação econômica melhor.

Com exceção de Leninha, todas as entrevistadas dizem que o que tiram da produção de doces e salgados é fundamental para a renda familiar, sendo, em dois casos, a única fonte de renda. Lamentam que a produção tenha diminuído nos últimos tempos e acreditam que isso se deva a maior concorrência..

Lazy diz que é difícil competir com alguns produtos comercializados hoje em dia em Paracatu:

Há uns disk-salgados que vendem um cento de pastel por 13 reais. Não tenho como competir com o pessoal que faz por carregação.

Outra razão seria a mudança de hábitos que levam as pessoas a preferir produtos industrializados que são mais baratos. Os jovens se interessam mais pelas modernas sobremesas com chantilly e pelas mousses.

A preocupação atual com as calorias é apontada, também, por Leninha como uma das razões das pessoas se interessarem menos pelos pratos tradicionais. Segundo ela, todo mundo hoje em dia prefere os alimentos diet ou light. 
César reclama das exigências dos/as seus/as fregueses/as que pedem seus bolos com menos açúcar ou com menos gordura, ora mais assados, ora menos assados. Para ela, o ideal é que se coma do jeito que sempre se fez.

Lazy não entende como se pode deixar de comer coisas gostosas pelo medo de engordar. Ela não come tanto quanto gostaria, por causa da diabetes. Pouco antes da entrevista que me concedeu, tinha estado internada no hospital pois exagerou numa marmelada que fez:

Há muito não fazia marmelada, mas fui a Brasília ... e comprei uns marmelos bonitos que vi por lá. Cheguei aqui, fiz a marmelada e ficou um trem tão gostoso que o povo adorou. Acabei comendo demais e fui parar no hospital.

De todas elas, Leninha é a única que não é otimista em relação ao aumento da produção. Diz que os doces são perecíveis, duram pouco tempo e relembra uma mal sucedida empreitada de uma conhecida sua que abriu uma doceria em Paracatu, que logo fechou.

Somente Maria Lúcia, ou Lucinha, como é chamada, contrata outras três mulheres, que trabalham diretamente em sua produção de salgados, além do seu marido, que se incumbe mais das embalagens e do pagamento. Ela produz em escala maior que as demais, enviando suas empadinhas freqüentemente para Brasília. De todas elas, foi a única que não pôde parar para a entrevista, entrevistei-a enquanto preparava as empadas, sem poder gravá-la.

As demais têm a ajuda das empregadas, quando as têm, ou de parentes, como sobrinhas e netas.

Os maridos são grandes incentivadores do trabalho que realizam. Valorizam o trabalho e percebem que é importante para a renda familiar. No caso de duas delas, os maridos participam ativamente da atividade, ajudando a preparar os produtos ou fazendo a entrega. Foi possível observar que estas mulheres exercem um forte poder em suas casas. Centralizam a atenção de filhos e maridos, que, em geral, ficam em torno delas, recebendo as instruções sobre a produção ou os detalhes da casa.

Principalmente os maridos circulam constantemente em torno delas, entram e saem da cozinha, para saberem como estão as coisas. Quando elas me recebiam na sala da casa, para concederem a entrevista de maneira mais formal, eles, muitas vezes, entravam e saiam, sem se fazerem notar, com gentileza e atenção para comigo e para com elas. Apesar de serem indiscutivelmente uma forte autoridade em casa, também no que diz respeito a renda familiar, estas mulheres demonstraram cuidado ao falarem sobre isso, procurando demonstrar também a importância deles. Na voz da maioria delas, percebia-se carinho e atenção para com os 
companheiros. Apesar de exercerem uma forte autoridade, que é reconhecida por elas mesmas e pelos familiares, não demonstram preocupação em expressá-la. Não é uma autoridade imposta e sim sutilmente e naturalmente conquistada.

Praticamente todas gostariam de aumentar a produção, se houvesse uma maior procura pelos seus produtos. Dizem que apesar da renda com os salgados e doces ser muito importante para elas, não é somente pelo dinheiro que gostariam de produzir mais, sentem prazer em ver seus produtos serem degustados, apreciados e valorizados pelas pessoas.

\section{3 - AS ESPECIALIDADES}

Duas das entrevistadas, Lavínia e César, são detentoras de um saber único e tipicamente paracatuense. Os livros de receitas consultados sobre a cozinha brasileira e mais especificamente mineira, não têm referências sobre o Bolo de Domingo, especialidade de César. Este bolo somente é feito aos domingos e sua tradição perdura em Paracatu. Segundo César, houve um resgate da tradição nos últimos anos, mas a produção não é a mesma de antes, quando as mulheres saiam com seus tabuleiros a distribuir pelas casas dos fregueses. Esses não passavam um domingo sem o tradicional bolinho para comer no café da manhã. César acredita que a tradição de fazê-lo só aos domingos deve-se ao fato das pessoas necessitarem ter algo em casa para servir às visitas, que sempre vinham aos domingos. Lilia Brochado, minha mãe e também moradora de Paracatu, diz que a tradição decorre do fato das padarias estarem fechadas aos domingos, o que tornava o bolo fundamental para o café da manhã.

O Bolo de Domingo é preparado com arroz triturado no pilão, junto com especiarias, como cravo e noz moscada. César diz que o segredo é o ponto pois as vezes fica mole demais e outras vezes duro demais, dificultando o preparo. Assim como algumas das entrevistadas, diz já ter dado sua receita para pessoas que pedem, mas que é difícil acertar. Se feito na forma tradicional, deve ser assado na folha de bananeira e vendido ainda enrolado na mesma.

Outra especialidade é a queijadinha tipicamente paracatuense. Lavínia é talvez a única que ainda a faça para vender. Aprendeu a fazer com sua patroa, ainda na fazenda. Também não encontrei referências a essa queijadinha nos livros consultados, principalmente com o seu formato, em forma de estrela. O único lugar que encontrei uma queijadinha parecida foi em Sintra, Portugal. No entanto a queijadinha de Paracatu é bem menor, do tamanho de uma tampinha de garrafa. As de Sintra, mandei para minhas mãe e avó, na época viva, e elas 
acharam bem diferente da que se faz em Paracatu. A queijadinha é feita com coco, ovo, queijo e farinha. Não levam leite, razão, segundo Lavínia, de durarem muito tempo.

Uma vez Dete de Silvinho me encomendou uma receita. Fui e entreguei pra moça que tava lá. Voltei depois pra receber e ela disse que não sabia de queijadinha nenhuma. Eu disse a ela: pode procurar aí, que a moça deve ter guardado. Ela procurou e encontrou a lata, abriu e disse que ainda tava fresquinha. E olha que fazia muito tempo!

Ela não alterou em nada a forma de prepará-las e como não tem filhas, nem parentes que saibam fazer, acredita que a tradição pode se perder. Perguntei-lhe se não gostaria de ensinar outras pessoas para que a tradição não morresse, ela disse:

Já perguntei a umas moças que conheço, se elas não queriam aprender, e sabe o que elas disseram? “eu, nem morta!” É muito trabalhoso e o povo não quer saber disso não.

Esta é uma iguaria muito especial, principalmente pela delicadeza da barquete em forma de estrela que abriga o creme para ser assado no formo. Pouca gente ainda a encomenda, já que os que ainda se lembram da queijadinha são os mais antigos moradores. Não vendendo em nenhum estabelecimento da cidade, já que não existe nenhum que valorize tal produto, somente pode ser adquirido sob encomenda, indo a casa de Lavínia, onde não há telefone. Para alguém que não é de lá, é praticamente impossível localizá-la, pois o paracatuense não tem por hábito saber o número das ruas dos lugares onde freqüenta e nem sequer os tem anotados. A referência é sempre nebulosa, tendo que ir perguntando as vizinhas até chegar ao destino que se deseja.

Outro produto típico de Paracatu, também escolhido para constar da pesquisa, é a empadinha de capa mole. Ao contrário da empada de capa podre, que se vende por todo o Brasil, a de capa mole só se encontra em algumas cidades de Minas e Goiás. Em Goiás encontramos algumas parecidas, mas estas são variações do Empadão Goiano. As de Paracatu, tem a massa bem mais fina e o recheio só leva um molho de galinha, se possível caipira, que escorre na boca quando está ainda quente. As vezes coloca-se também milho verde e azeitona. Todo mundo sabe que é impossível comer uma só.

Lucinha que o diga, já que sua produção é a que mais aumentou entre as entrevistadas. É uma micro-empresária, empregando, como já disse, outras mulheres. Vende suas empadas em Paracatu e constantemente envia encomendas para Brasília. Diz que aprendeu a fazer as 
empadinhas “com mulheres de Paracatu” e que já ensinou para uma mulher de Paracatu que está fazendo empadas em Nova York.

Lazy, no entanto, reclama do desinteresse pelos cursos de culinária. Diz que algumas mulheres lhe pediram que desse um curso para ensinar o que sabia:

Inscreveram trinta, apareceram cinco e ficaram três

Essa mulher, a mais velha de todas as entrevistadas, é detentora de uma sabedoria culinária que impressiona. Prepara uma grande variedade de pratos, receitas antigas, muitas, segundo diz, trazidas a Paracatu pelo seu bisavô português. Este veio ao Brasil atrás do seu pai, Ricardo Sarafim da Costa Porto, tataravô de Lazy, que tendo vindo para comprar pedras preciosas no Brasil, apaixonou-se pela famosa Chica da Silva, não retornando a Portugal. Teria sido ele o responsável por satisfazer as vontades de Chica, transformando-a em personagem histórico por suas excepcionalidade e excentricidade.

Sua mãe morreu aos 39 anos, quando Lazy tinha 9, deixando 17 filhos. Lazy aprendeu os famosos pratos que até hoje encanta a quem entra em sua grande cozinha de janelões, com sua avó e sua tia. Enquanto conversava comigo, ficava de olho na rosca que há pouco havia colocado no forno. Enquanto isso, preparava uma cocada feita com açúcar queimado, que sem poder resistir à tentação provocada pelo cheiro tomava conta da cozinha, experimentei. Até hoje não havia comido cocada igual, era um caramelo que derretia na boca, dando vontade de engolir aquilo, sem esperar que se dissolvesse totalmente. Acabei encomendando algumas para levar a Brasília e as pessoas que experimentaram, pelo que me disseram e demonstraram com suas expressões de prazer, tiveram uma experiência degustativa semelhante à minha.

A rosca, que também comprei, ficou perfeita com o cafezinho da tarde, tradição tipicamente mineira que até hoje não pode faltar principalmente nas casas do interior.

Lazy faz, também, leitão à pururuca, que assa em pé, como gosta de frisar, no seu grande fogão, além de pernil, lombo etc. Pensa na possibilidade de abrir sua cozinha para receber amigos para almoçar no domingo, mas diz que já está cansada e que sua neta, que também gosta muito de cozinhar e que poderia ajudá-la, não quer ficar em Paracatu, pela falta de perspectivas da cidade. Sua filha mais nova, que também pensou em trabalhar com ela nesse antigo projeto, já se foi para Brasília há alguns anos. A idéia surgiu quando amigos e amigas, velhos/as conhecedores/as de seus dons culinários, pediram para que ela preparasse almoços em sua casa, mas que só viriam se ela cobrasse por eles. 
Lazy, no entanto, apesar do prazer que sente em cozinhar e ver as pessoas degustando o que faz, se diz muito cansada. Sente muitas dores nas pernas e nas costas, em função de uma enfisema pulmonar adquirida nos anos de cabelereira:

Tenho enfisema por causa de cigarro. Não meus, que eu nunca fumei, mas das freguesas do salão. Fui fumante passiva durante muitos anos.

Além do salão de beleza, ela teve também com o seu marido, Horácio, uma famosa padaria em Paracatu, a Vesúvio.

Vânia aprendeu a fazer os salgados que vende com a mãe, que teve uma fábrica de biscoitos em Paracatu. A mãe faleceu, a fábrica fechou, mas Vânia continuou a fazer os salgados que vende.

Sua especialidade é o pão-de-queijo, segundo Lucinha, que como ela faz salgados, “o melhor da cidade”. Conserva as receitas do jeito que aprendeu com a mãe e também não altera os ingredientes.

Ela diz que por ter filhos ainda crianças, o trabalho em casa é o ideal, já que pode, ao mesmo tempo, cuidar da criação deles.

Eugênia aprendeu a fazer os doces que vende, com D. Cota, mulher de seu João da Farmácia, com quem trabalhou por mais de 20 anos. Faz uma variedade enorme de doces, os típicos das festinhas de aniversário de Paracatu, certamente bem guardadas na memória de qualquer um de lá: cajuzinho, olho-de-sogra, canudinho, amor-em-pedaço etc. Vende para Brasília, Belo Horizonte, “até pra França já levaram”. Ajudam-na duas sobrinhas “quando tem muita encomenda”. Diz que quando vê tudo aquilo pronto, não acredita que foi ela que fez e sente um cansaço cheio de satisfação.

As mulheres que entrevistei demonstram também um caráter solidário. César, que vive com dificuldade, tirando do Bolo de Domingo quase toda a renda da família, sempre leva os bolos que sobram para o asilo da cidade, chamado antigamente de Abrigo:

Às vezes sobram muitos pois tem domingo que dá cem reais e outros que dá vinte. Os que sobram, eu levo pro Abrigo.

Tive o prazer de ver os pirulitos que Lucinha havia feito para distribuir no Dia das Crianças. Eram de açúcar queimado, em vários formatos: chupeta, flor, carrinho etc. Saí de lá 
com um na boca, depois de comer algumas empadas que ela me ofereceu. Mineiro sabe que não se pode recusar os oferecimentos do/a anfitrião/ã.

\section{4 - ELAS E O TURISMO}

Como já disse, com exceção de uma, todas as demais entrevistadas, vêem com otimismo a possibilidade de aumentarem sua produção. Gostariam de ver seus doces e salgados conhecidos e apreciados por um maior número de pessoas. A maioria delas sobrevive com dificuldade numa cidade que oferece poucas possibilidades profissionais, tendo que criar filhos/as e, algumas vezes, ajudar na criação dos/as netos/as, os quais não terão também muitas perspectivas profissionais se permanecerem em Paracatu.

Quando perguntadas se acreditam que o turismo possa ajudar a divulgar e vender os seus produtos, responderam afirmativamente, demonstrando um grande entusiasmo com essa possibilidade.

Acham que Paracatu tem coisas bonitas a mostrar "pra gente de fora”, mas que falta um maior interesse das autoridades em divulgar a cidade e melhorar a infra-estrutura para receber as pessoas.

Acreditam também que a comida de Paracatu, seus quitutes em geral, possam ajudar a atrair os visitantes e que esta seria uma forma de preservar as tradições que estão se perdendo pela falta de valorização.

Sentem pena da tradição culinária "não estar mais valendo o que já valeu”, nas palavras de Lavínia que, apesar de não saber o que é turismo, sabe o que é visitante e diz que seria bom que esses conhecessem sua queijadinha. 


\section{CAPÍTULO III - CONSIDERAÇÕES FINAIS}

Porque escrever sobre minha terra natal, foi um de meus questionamentos. Remeto-me ao texto de Willi Bolle interpretando a obra de Walter Benjamin, principalmente os escritos sobre sua infância em Berlin, “uma tentativa de preservar, através do registro escrito, a memória do que era essa cidade, antes que fosse destruída” (1984, p.12). Ele resgata a infância para buscar o mundo cultural de seus pais. A busca aqui é da identidade, identidade que Walter Benjamin provavelmente tentava manter como forma de dizer não ao que lhe chegava naquele contexto que lhe era especialmente brutal, o período nazista. Dentre as recordações estão as suas lembranças açucaradas em geléias, chocolate e mel.

O que o turista vai buscar ao escolher como destino uma cidade do interior? Provavelmente a tranqüilidade das cidades que não têm pressa, que param para o cafezinho da tarde, sempre acompanhado dos bolos e biscoitos, do pão-de-queijo. É o fascínio pelo movimento lento dos que param para prosear, para jogar conversa fora. O fascínio surge em função da falta: desconhecem isso em suas grandes cidades, completamente dependentes dos relógios que não esperam, que não desculpam a subjetividade humana. Surge também de recordações contidas na memória revividas nas cores, cheiros e sabores dessas cidades.

E Paracatu, como já sabia empiricamente, possui um potencial impressionante para satisfazer aos que procuram o que acima descrevo, como pôde ser examinado aqui. Tem uma história que, pela sua idade e importância no contexto histórico nacional, acompanha a do Brasil, sendo, muitas vezes, reflexo desta em momentos de apogeu e decadência. Possui também elementos identitários importantes e esta pesquisa mostrou que a culinária é um deles.

A pesquisa oral, dentre as várias aportações, trouxe uma fundamental: a constatação do prazer demonstrado pelas mulheres ao falarem do que fazem. Demonstram uma relação afetiva com o alimento que elaboram, com suas especialidades. Essa relação, no entanto, provoca ao mesmo tempo um sentimento de nostalgia com relação ao que esses produtos representaram no passado. Da mesma maneira que parecem temer pelas tradições culinárias da cidade, se entusiasmam com a possibilidade de que haja uma valorização dos seus produtos.

Foi possível observar, igualmente, na pesquisa oral, que a culinária é um espaço de poder feminino e que sua autoridade é reconhecida. No entanto, essa autoridade é exercida de maneira sutil, sem necessidade de imposição ou alarde. 
A pesquisa em turismo é uma das saídas para os dilemas que o fenômeno hoje apresenta já que subsidiam o planejamento turístico. Espero que esta possa contribuir de alguma maneira para a cidade de Paracatu, seu povo, suas tradições e identidades. E também para os que buscam em suas viagens um sair de si e, principalmente, um voltar a si mesmos. 


\section{BIBLIOGRAFIA}

AGUIAR, Ana Cláudia de, A Comunidade é a Guardiã do seu Patrimônio?, BH: Arquimemória II, 1987 (apostila).

ANDRADE, José Vicente. Turismo Fundamentos e Dimensões. 8. ed. SP: Ática, 2002. ARAÚJO, W.M.C, GINANI, V.C., BOTELHO, R.B.A. e ARAÚJO, H.M.C. A “A Gastronomia no Brasil: Estudos Preliminares”. In: Alexandre Shigunov Neto (org.). Reflexões sobre o Mercado de Trabalho para os Bacharéis de Turismo e Hotelaria, Campo Largo: Faculdade Cenecista Presidente Kennedy (prelo)

ARBACHE, Jorge Saba. O Mercado de Trabalho na Atividade Econômica do Turismo no Brasil. DF: Ed. Universidade de Brasília, 2001.

BANDUCCI, Álvaro; BARRETTO, Margarita (Org.). Turismo e Identidade Local: uma visão antropológica. 2. ed. Campinas, SP: Papirus, 2001.

BARBOSA, Ycarim Melgaço. História das Viagens e do Turismo. SP: Aleph, 2002.

BARBOSA, Ycarim Melgaço. O Despertar do Turismo: Um Olhar Crítico sobre os NãoLugares. SP: Aleph, 2001.

BARRETTO, Margarita. “As Ciências Sociais Aplicadas ao Turismo”. In: Heloísa Célia Serrano; Maria Tereza Turini Bruhns; D. P. Luchiari, (Orgs.) Olhares Contemporaneos sobre o Turismo . SP: Papirus, 2001.

BERTRAN, Paulo. História da Terra e do Homem no Planalto Central. BSB: Ed. Verano, 2000.

BOLLE, Willi. “Walter Benjamin. Infância berlinense por volta de 1900”. In: ARANTES, Antonio Augusto (Org.) Produzindo o Passado. Estratégias de construção do patrimônio cultural. BSB: Ed. Brasiliense, 1984.

BOTELHO, Branca Adjucto. Simplicidade. MG: Ed. DPI,2003.

BOTELHO, Maria Conceição Adjucto. Amenizemos a vida e outros textos. BSB: Gráfica Artgraf, 1997.

BRUHNS, Heloísa Turini. “ No Ritmo da Aventura: Explorando Sensações e Emoções. In: Alcyone Marinho; Heloísa Turini Bruhns (Org.). Turismo, Lazer e Natureza. SP: Manole, 2003.

CARNEIRO, Henrique. Comida e Sociedade. Rio de Janeiro: Campus, 2003. 
FLANDRIN, Jean-Louis; MONTANARI, Massimo (Org.). História da Alimentação. SP: Estação Liberdade, 1998.

FRANCO, Ariovaldo. De caçador a gourmet: uma história da gastronomia. 2. ed. SP: Ed. SENAC, 2001.

GARCIA, Rosa Wanda Diez. "Reflexos da globalização na cultura alimentar: considerações sobre as mudanças na alimentação urbana”, In: Revista de Nutrição. Campinas, 16(4): 483492, out./ dez., 2003.

HALL, Stuart. A questão da Identidade Cultural. Campinas. SP: IFCH, Unicamp, Textos didáticos n. 18, 1995.

HALL, Stuart. A Identidade Cultural na Pós-Modernidade. RJ: DP\&A, 1997.

KRIPPENDORF, Jost. Sociologia do Turismo. SP: Aleph, 2000.

LABATE, Beatriz Caiuby, “A experiência do "viajante-turista” na contemporaneidade”, In:

Heloísa Célia Serrano; Maria Tereza Turini Bruhns; D. P. Luchiari, (Orgs.) Olhares

Contemporaneos sobre o Turismo . SP: Papirus, 2001, p. 55-80.

LOUREIRO, Zenóbia Vilela. O Sobradinho. MG: Ed. Santa Edwiges, 1996.

MARTINS, Maria do Socorro de Melo. “O Philodramático: Memórias de Uma História”. In:

Helen Ulhôa Pimentel (Org.). Uma Cidade, Muitas Histórias. Paracatu, MG: Prefeitura

Municipal de Paracatu, 1998.

MELLO, Oliveira. Paracatu do Príncipe: minha terra. Paracatu, MG: Edição da Academia

Patense de Letras, Prefeitura Municipal de Paracatu, 1979.

MELLO, Oliveira. As Minas Reveladas (Paracatu no Tempo). Paracatu, MG: Ed. da

Prefeitura Municipal de Paracatu, 2002.

MELLO, Oliveira. Memória Cultural (A cultura em Paracatu). BH: Ed. da Comissão Mineira de Folclore, 1990.

MELLO, Oliveira. Memórias de um tempo. Paracatu, MG: Edição da Academia de Letras do Noroeste de Minas, 1999.

MELLO, Oliveira. Paracatu do tempo e em tempo. Paracatu, MG: Prefeitura Municipal de Paracatu, 2001.

MIRANDA, Teresinha de Jesus Neiva. Passado que não passou. Anápolis, 1992.

MARINHO, Alcyone; BRUHNS, Heloísa Turini (Org.). Turismo, Lazer e Natureza. SP:

Manole, 2003.

NORA, Pierre, Estudos Históricos, Rio de Janeiro, vol. 2, n. 3, 1989.

NORONHA, Wanda Costa. Paractu: Delícias da Casa Grande. MG: Ed. Gráfica da Fundação Cultural de Belo Horizonte, 1994. 
ORNELLAS, Lieselotte Hoeschl. A alimentação através dos tempos. SC: Ed. Universidade Federal de Santa Catarina, 2000.

PELLEGRINI FILHO, Américo. Ecologia, Cultura e Turismo. SP: Papirus, 2001. POHL, Johann Emanuel. Viajem no Interior do Brasil. Trad. de Milton Amado e Eugênio Amado. SP: Ed. da Universidade de São Paulo, 1976.

POULAIN, Jean-Pierre, “Reflexões metodológicas para o estudo das práticas aliementares”, In: Revista de Nutrição. Campinas, 16(4): 365-386, out./ dez., 2003.

POLLAK, Michael, “Memória e Identidade Social”. In: Estudos Históricos, vol. 10, Rio de Janeiro, 1992.

RODRIGUES, Adyr Balastreri. Turismo Desenvolvimento Local. 3. ed. SP: Hucitec, 2002. RODRIGUES, Adyr Balastreri. Turismo e Espaço. Rumo a um conhecimento transdisciplinar. 3. ed. SP: Hucitec, 2001 SCHLÜTER, Regina G.. Gastronomia e Turismo. SP: Aleph, 2003.

SERRANO, Heloísa Célia. “Poéticas e Políticas das Viagens”. In: Heloísa Célia Serrano; Maria Tereza Turini Bruhns; D. P. Luchiari, (Orgs.) Olhares Contemporaneos sobre o Turismo . SP: Papirus, 2001, p. 37-53.

TRIGO, Luiz Gonzaga Godoi. Viajem na Memória: Guia Histórico das Viagens e do Turismo no Brasil. SP: Ed. Senac, 2000. 